\title{
Retcam shuttle images of developing retinopathy of prematurity
}

\author{
Zainab Bello
}

University of Manchester, Manchester, UK

Correspondence to Zainab Bello, Zainab.bello@ student.manchester.ac.uk

\section{DESCRIPTION}

A female baby was born at 24 weeks gestation, weighing less than $600 \mathrm{~g}$. Owing to the extremely low birth weight and gestation age, she was at risk of developing sight threatening retinopathy of prematurity $(\mathrm{ROP})^{1}{ }^{2}$ and therefore eligible for screening, which subsequently demonstrated the development of severe ROP in the left eye. She was referred to a different hospital for more detailed evaluation and treatment. Severe ROP was confirmed in the left eye as well as the right eye. It was apparent on examination that the left eye exhibited stage 3 ROP in zone 1 , the most posterior zone in the retina. There were also features of florid 'plus disease', with increased dilation and tortuosity of the retinal vasculature as demonstrated by figure 1B. The left eye also showed flat neovascularisation in a 'sea fan' formation (see arrows in figure 1B).

The right eye, figure $1 \mathrm{~A}$, revealed less advanced ROP and was characterised as stage 2; however, the demarcated line separating the avascularised region was bordering on zone 1 . There was slight tortuosity of the vessels, which is characteristic of a pre-plus presentation.
In addition, both eyes exhibited iris vascular engorgement.

According to the guidelines produced by the Royal College of Paediatrics and Child Health, she met the criteria for laser ablation especially due to the presence of type 1 prethreshold ROP. Within $48 \mathrm{~h}$, she underwent bilateral diode laser treatment, receiving more burns on the left, 3378, than on the right, 2865, eye. Figure 2 shows the avascularised regions that have been treated.

\section{Learning points}

- Retinopathy of prematurity (ROP) is a preventable cause of blindness ${ }^{1}{ }^{2}$; therefore, adequate screening of high-risk groups is essential.

- In the UK, newborns with a gestational age of less than 32 weeks or weighing less than $1501 \mathrm{~g}$ should be included for screening. ${ }^{2}$

- Non-aggressive posterior ROP should ideally be treated within $48-72 \mathrm{~h}$ of presentation. ${ }^{2}$
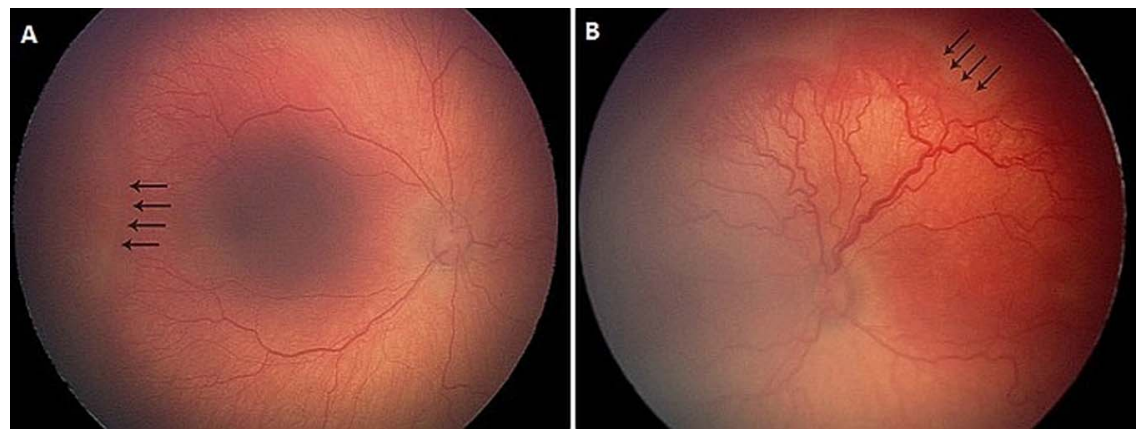

Figure 1 Wide angle digital (Retcam shuttle) images of the retina in the right (A) and left eye (B). Arrows demonstrating line of demarcation.
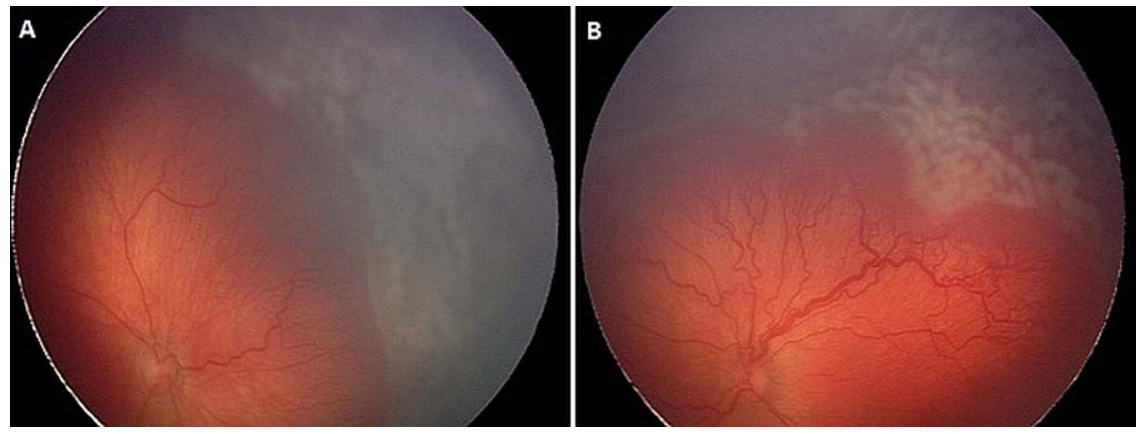

Figure 2 Postoperative images of the retina in the right (A) and left eye (B). 
Acknowledgements Susmito Biswas was responsible for producing the images that were used in this report.

Competing interests None.

Patient consent Obtained.

Provenance and peer review Not commissioned; externally peer reviewed.

\section{REFERENCES}

1 Reynolds JD. Retinopathy of prematurity. Int Ophthalmol Clin 2010;50:1-13. (accessed 01.07.2014)

2 Royal College of Paediatrics and Child Health. Screening and treatment of retinopathy of prematurity. http:/www.rcpch.ac.uk/system/files/protected/page/ROP\%20Guideline \%20-\%20Jul08\%20final.pdf (accessed 01.07.2014).

Copyright 2014 BMJ Publishing Group. All rights reserved. For permission to reuse any of this content visit http://group.bmj.com/group/rights-licensing/permissions.

BMJ Case Report Fellows may re-use this article for personal use and teaching without any further permission.

Become a Fellow of BMJ Case Reports today and you can:

- Submit as many cases as you like

- Enjoy fast sympathetic peer review and rapid publication of accepted articles

- Access all the published articles

- Re-use any of the published material for personal use and teaching without further permission

For information on Institutional Fellowships contact consortiasales@bmjgroup.com

Visit casereports.bmj.com for more articles like this and to become a Fellow 